\title{
THE EFFECT OF RELATIONSHIP QUALITY ON LONG-TERM RELATIONSHIPS BETWEEN CONSTRUCTION CONTRACTORS AND CEMENT SUPPLIERS IN BOGOR, INDONESIA
}

\author{
Aditya Mochammad Ridwan* \\ School of Business, IPB University, Indonesia \\ Fahmi Idqan \\ School of Business, IPB University, Indonesia \\ Yuliati Lilik Noor \\ Faculty of Human Ecology, IPB University, Indonesia \\ *E-mail: aanditopurbo@gmail.com
}

\begin{abstract}
Cement production capacity in Indonesia continues to increase, but this condition is not matched by an increase in cement consumption. Cement consumption in Indonesia only reaches $61 \%$ of its production. The low consumption of cement makes competition in cement suppliers in Indonesia. But Indonesian contractors are able to be one of the targets to optimize cement sales. The research objective is to analyze the effect of relationship quality on the long-term relationship between the contractor and the cement supplier through identification, analysis and formulation of possible strategies. The results of the study stated that long-term relationships have a real relationship with commitment and satisfaction. In commitment has a real relationship with trust as well as satisfaction has a real relationship with trust, price satisfaction and supply strategy. The strategies formed include using a separate communication tool specifically used to provide information to contractor consumers. In addition, by optimizing profits through the quantity of cement sold at lower prices. And use a longer term of payment with high minimum order requirements.
\end{abstract}

\section{KEY WORDS}

Commitment, long-term relationship, price satisfaction, satisfaction, supply strategy, trust.

Cement is one of the construction materials which are needed for the infrastructure development. Through the years the production capacity of cement in Indonesia keeps growing. Yet, the market's demand of the mentioned product is still yet to reach the produced quota. The market's demand of cement in Indonesia is only $61 \%$ of the production capacity of the existing companies. With the numerous brands existing in the market, it results in high competition on selling the product.

The condition of cement market in Indonesia until recently is still dominated of somecertain brands of cement. This condition forces the cement suppliers, either distributor or sub-distributor, to re-think about marketing strategy to optimize their number of selling. Relationship with building developer is one of the important strategy to increase the selling of cement. Initiating a long-term relationship with those developers is crucial for suppliers to increase the selling and maximize the profit.

Figure 1 informs that the expenditure for infrastructure development increases each year. This shows that the role of building developers in increasing the suppliers' selling is high in Bogor District. Therefore, establishing long-term relationship between suppliers and building developers is deemed to be able to increase the profit of suppliers.

Long-term relationship is formed by the mutualism assumption of both side, therefore the relationship is expected to be beneficial for both party in the long term (Ganesan, 1994). In the relation between companies or individual in long term relationships, relationship quality which includes trust, satisfaction and commitment becomes crucial factor to be noted 
(Lungtae and Atthirawong, 2014). There are several researches that use relationship quality to analyze its influence towards long-term relationship conducted by Lungtae, Atthirawong, Bonifae, Gyau, and Stinger which has been published.

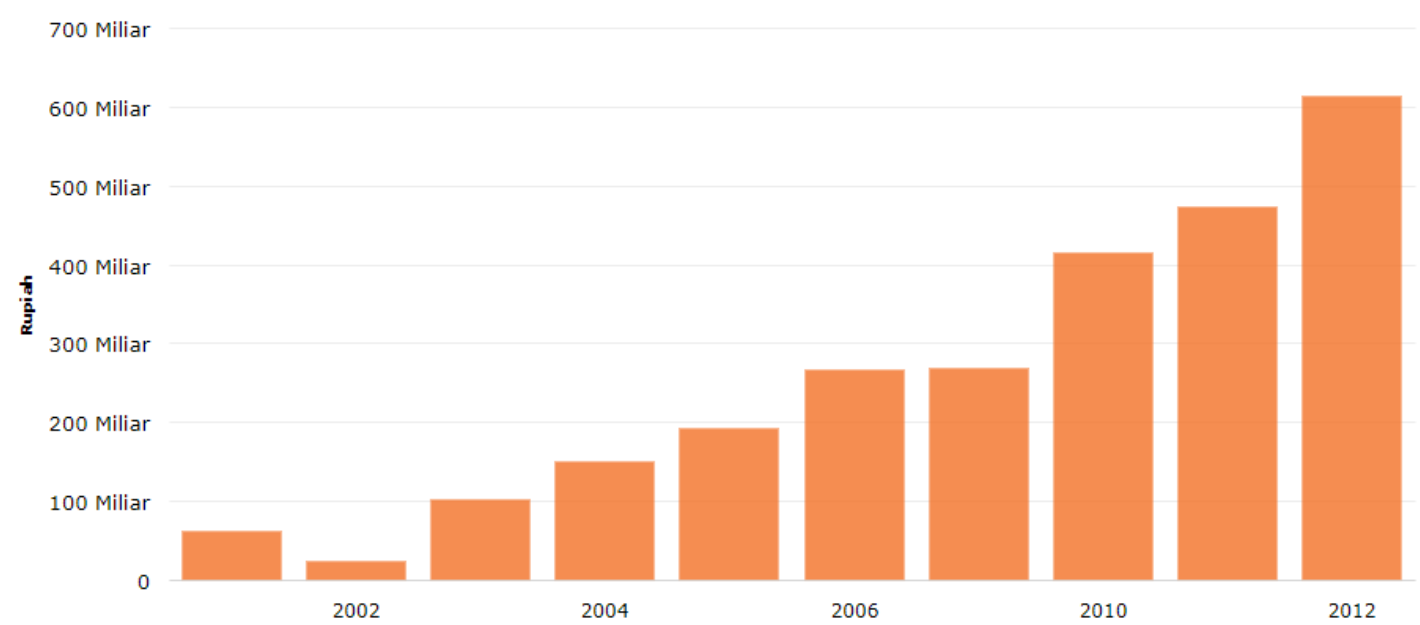

Figure 1 - Government Expenditure for developing infrastructure of Bogor District 2001-2012 (Source: Databoks, 2016)

The goal of this research are to identify the level of supply strategy, price satisfaction and trust, satisfaction and commitment between developers and suppliers in Bogor, also to examine the influence of supply strategy, price satisfaction and trust, satisfaction and commitment towards long-term relationship between suppliers and developers.

The focus of this study is the transaction between cement suppliers and developers from the perspective of developer as respondent, which fulfill two criteria which are: the developers were established for at least 5 years, and domiciled in Bogor District. This study includes relationship qualities which are trust, satisfaction, and commitment also the correlation of price satisfaction and supply strategy towards satisfaction with long-term relationship as dependent factor.

\section{THEORETICAL FRAMEWORK}

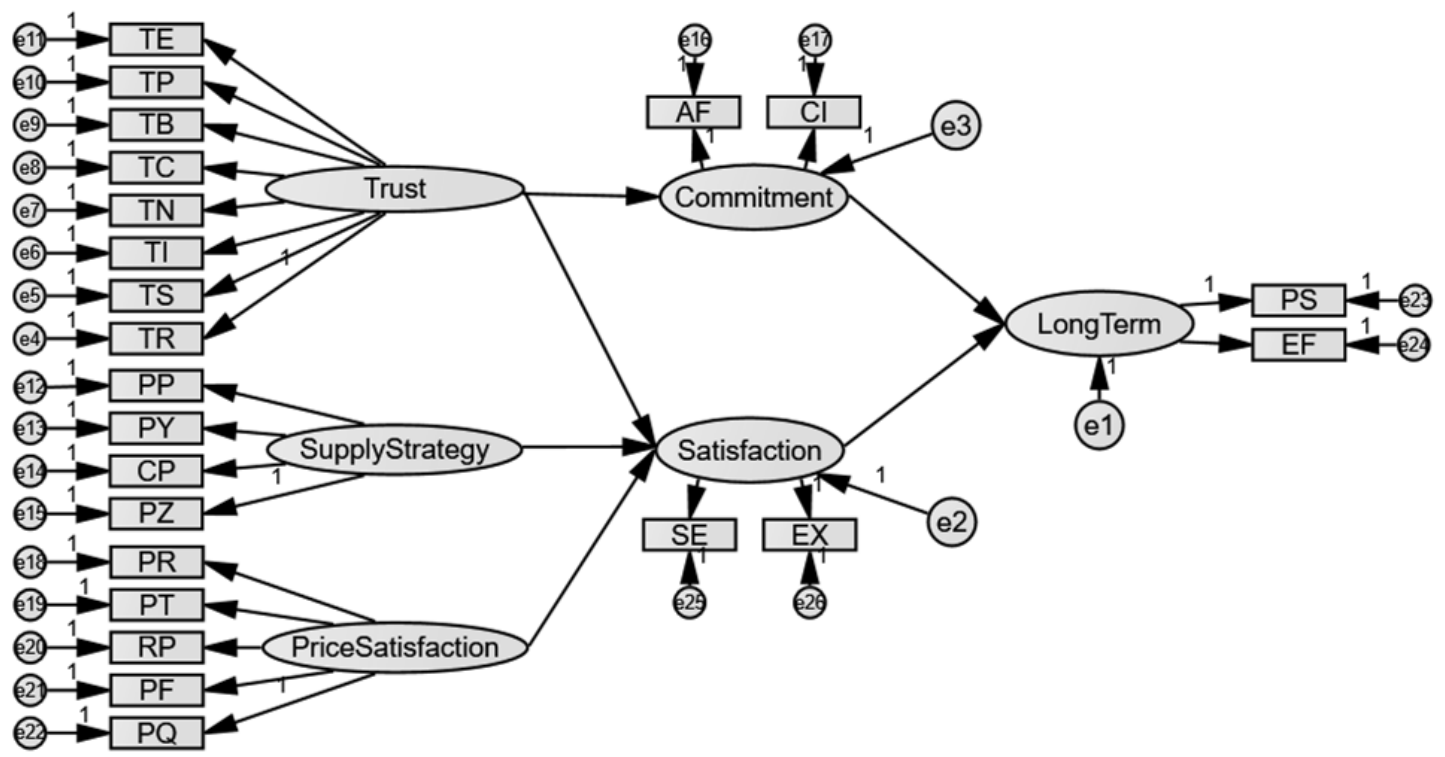

Figure 2 - Study Framework 
The above theoretical framework explains that there are several variables also indicators that influence them. The exogenous variable includes price satisfaction, supply strategy, and trust while the latent endogenous variables consist of satisfaction, commitment and long-term relationship according to the developer.

The hypothesis of the study formed by adopting and fuses the theories from the previous study of experts which have some relevance with this study in order to know the factors which affect long-term relationship between developers and cement suppliers.

Table 1 - Research hypothesis

\begin{tabular}{ll}
\hline Hypothesis & Description \\
\hline $\mathrm{H} 1$ & Supply Strategy gives positive impact towards Satisfaction \\
$\mathrm{H} 2$ & Price Satisfaction gives positive impact towards Satisfaction \\
$\mathrm{H} 3$ & Trust gives positive impact towards Satisfaction \\
$\mathrm{H} 4$ & Trust gives positive impact towards Commitment \\
$\mathrm{H} 5$ & Satisfaction gives positive impact towards Long-term Relationship \\
$\mathrm{H} 6$ & Commitment gives positive impact towards Long-term Relationship \\
\hline
\end{tabular}

In competitive business, customer tends to choose a long-term relationship with the a certain choosen supplier in satisfying the needs hoping that it will reduce the operational cost and unexpected cost in the future (Walter et al., 2003). Long-term relationship with supplier is able to reduce potential problem and risk which leads to supply product needed (Gerrit et al., 2001) and increasing reliability (Han et al., 1993). Somogyi (2010) states that long-term relationship increases the benefit of both parties participated, while also gives competitive price to maximize the income. The long-term relationship is formed by the assumption of dependency of corresponding party, therefore the long-term relationship is expected to be able to give benefit for both party continuously (Ganesan, 1994). In this case long-term relationship is an important aspect to be kept in mind in business world. The high degree of satisfaction, trust, and commitment with low possibility of conflict is an important characteristic of long-term relationship with good quality (Coleman amd Robicheaux, 1994; Morgan and Hunt 1994). With regard to good relationship quality, will give positive impact on long-term relationship. Lingtae and Atthirawong (2014) argue that there are two indicators in long-term relationship which are positive response which is positive reaction given to the consumer towards consumed product, and expected future sell which is future hopes of the product, corresponding or not, with the expectation of the consumer.

Trust is the belief and confidence that individual, institution, or company has towards certain product, company as well as individual, and is formed by certain factors that influence it. Trust is the fondation of the forming of relationship (Das and Sharma, 2017). In relationship quality, trust becomes irreplacable in developing commitment of consumer towards product. By the reason of the foundation of commitment is trust that consumer has towards certain product, can be concluded that trust is belief and confidence which establish important relationship model and will gives the best treatment towards the other party (Wilson, 1995). Trust is an important aspect in the development of loyality and long-term relationship. With high degree of trust that consumer has towards certain product will increase the purchase rate of the consumer. Trust is very crucial as the variable of commitment in inter-organization relationship (Doney and Cannon, 1997; Garbarino and Johnson, 1999). Trust is also an important element in existing commerce relationship stability amd becomes the mediator between satisfaction and commitment (Cater and Cater, 2010). The important role of trust is as the variable that able to establish commitment from the consumer, other than that, the main use of trust is the formation of satisfaction (Bricci et al., 2016).

Commitment is self-acknowledgement that appear inside oneself towards something as a whole. Commitment is desire of developing, maintain, and perserve a long-term relationship and the company is willing to expend certain cost to get it (Das and Sarma, 2017). The high degree of commitment that someone has is able to increase relationship quality which is intertwined therefore a long-term relationships is formed between sides. Consideration towards commitment is a the key of the success of a relationship (Morgan and 
Hunt, 1994). Many researchers say that commitment is a lasting wish to perserve the value of a relationship (Mooran, Zaltman, Deshpande, 1992). An effective commitment is included in the will for developing and strengthten a relationship someone has towards someone or group because of kinship, friendship, and personal trust that formed through sustianed interpersonal interaction (Sharma et al., 2006). Therefore commitment becomes the foundation of the forming of long-term relationship (Anderson and Weitz, 2013).

Satisfaction is the key and closely related with relationship quality. High degree of satisfaction that consumer has toward something will result in better relationship (Dorsch, Swanson, Keller, 1998). Satisfaction defined as positive emotion that consumer has, his assessment, towads something. Satisfaction usually defined as assessment towards working relationship between a certain company towards other company (Anderson and Narus 1990; Geykens et al., 1999). Furthermore Kotler (1994) says that the key in buying back the consumer is through satisfaction they receive from consumer. Satisfaction is crucial in relationship and is proven able to give big role in enhancing cooperation also becomes the breaker of relationship (Ganesan, 1994). Satisfaction is an important variable in explaining the forming of loyality (Heskett et al., 1997). Pleased consumer will give his loyalty to a certain company (Eriksson and Vaghult, 2000), loyality towards the company in this case means that the consumer will always use the product of the company.

Price satisfaction is a factor that will give impact on competitiveness and the rate of success on business or company. The higher the price satisfaction will increase satisfaction in relationship quality therefore it will birth on long-term business relationship (Lingtae and Atthirawong, 2014). Price Satisfaction is a crucial aspect on increasing satisfaction in relationship quality. This happens because satisfaction from consumer's (B2B) side towards the price of certain goods or services, the B2B consumer will allocate more funds to maintain better relationship with supplier that will reduce the cost (Pick and Eisend, 2014; Negengast et al., 2014; Russo Confente et al., 2016). From the existing research there are five factors that will influence price satisfaction, which are: Price reliability, relative price, price-quality ratio, price fairness, and price transparency (Lungtae and Atthirawong, 2014; Boniface, 2012; Gyau et al., 2011).

Table 2 - Operational Definition

\begin{tabular}{|c|c|c|}
\hline $\begin{array}{l}\text { Exogenous } \\
\text { Variable }\end{array}$ & Definition & Source \\
\hline Price Satisfaction & \multirow{3}{*}{$\begin{array}{l}\text { Positive emotion which consumer had towards the pricing of goods or service. } \\
\text { Planning of action in order to improve the long-term relationship, paying } \\
\text { attention of the quantity and stock of the needed goods available. } \\
\text { The will of consumer in forming relationship model which result in the best } \\
\text { treatment between both parties in for the sake of mutual benefit. }\end{array}$} & $\begin{array}{l}\text { Lungtae and } \\
\text { Atthirawong (2014) }\end{array}$ \\
\hline Supply Strategy & & $\begin{array}{l}\text { Chopra and Meindl, } \\
2009\end{array}$ \\
\hline Trust & & Wilson (1995) \\
\hline $\begin{array}{l}\text { Endogenous } \\
\text { Variable }\end{array}$ & Definition & Source \\
\hline Satisfaction & Positive emotion of the consumer in valuing certain goods/service. & Dorsch et al. (1998) \\
\hline Commitment & $\begin{array}{l}\text { The will to develop, maintain, and preserve long-term relationship also willing to } \\
\text { spend money in order to get it. }\end{array}$ & $\begin{array}{l}\text { Das and Sharma, } \\
\text { (2017) }\end{array}$ \\
\hline $\begin{array}{l}\text { Long-term } \\
\text { Relationship }\end{array}$ & The willingness to do cooperative relationship in the future. & Boniface et al. (2012) \\
\hline
\end{tabular}

Supply strategy becomes one of the factor that will influence towards satisfaction in relationship quality especially in $\mathrm{B} 2 \mathrm{~B}$ model. In $\mathrm{B} 2 \mathrm{~B}$, companies or organization need product in bigger quantity, therefore in B2B model supply strategy is able to increase satisfaction in relationship quality with consumer. Strategy to improve the relationship can be senn from complexity of the market supplier and the number of product. (Chopra and Meindl, 2009). Supply strategy has an effective role towards customer satisfaction (Kamil and Gurkan, 2013). Good supply strategy will give positive result towards customer satisfaction, especially B2B customer. There are several variable in supply strategy (Lungtae and Atthirawong, 2014) they are a) Purchasing policy which includes several activities such as buying, product and shipping and has influence towards satisfaction depending on the shipping response, time of shipping, communication regarding information that the buyer gets (Esigg and 
Amann, 2009) b) Payment policy which related to process, procedure amd condition about payment method that can be used which also influence the satisfaction of the buyer (Esigg and Amann, 2009). In this case, it is very likely for the developer to chose the payment method using term of payment which is a payment using certain span of time, c) Coordination policy is policy in coordinating related to the product including giving information, arrangement up to agreement regarding something without disturbing duty and execution process of each party. Better coordination policy will enhance the policy in procurment and result in good reputation (Esigg and Amann, 2009). This will lead to satisfactory result between buyer and seller and will create good image in the process. d) Buyer size, this is more of the capacity of the buyer related to certain product (Gyau et al., 2011).

\section{METHODS OF RESEARCH}

This research is conducted in Bogor territory and the data collecting process happens between July-December 2018. The type and data source used in this research are primary and secondary data. The methods of gathering data are through both interview and questionnaire as the helping tool which uses 6 Likert scale, Rungson (2010) states that Likert Scale using 6 levels is able to give discrimination and better reliability value. With sampling respondents of building developers which domiciled in Bogor, developer companies which have SIUP and SIUJK for developing infrastructure, developers which are already existed for at least 5 years with experience in at least doing 3 projects in the last 5 years. The sample size in this research calculated using Hair (2006) formula by regarding on the available indicator number times by 5 , so that $23 \times 5=115$ respondents, therefore the sample taken are 125 considering 10 percent in case of data drop outs.

In data processing and analysis, descriptive analysis used by gathering and presenting the data using percentage model in each variable and SEM analysis, using software as a helping tool in processing it. In formulating strategy, connection from the result of distribution value of respondents which are considered less sufficient in descriptive manner, are being compared against loading factor value of each indicator which has bigger impact. Whereas in deciding the strategy sequence done by looking the value of loading factor of the direct variable which has bigger impact compared to other variable, then going to loading factor which has less value compared to previous variable.

\section{RESULTS AND DISCUSSION}

Degree of Relationship Quality between Developer and Cement Supplier. Obtained from distribution of respondents that buying behavior is $16 \%$ in main distributor, $38.4 \%$ in sub-distributor and $45.6 \%$ in building material shop. And for the cement brands, the buying behavior percentage is $27.2 \%$ for Semen Tiga Roda brand, $25.2 \%$ for Holcim brand, $19.6 \%$ for Semen Merah Putih brand, and $14.6 \%$ for Semen Gersik brand. Whereas according the project value, $59.2 \%$ is developer with project value under Rp.2.5 billion and $38.4 \%$ is developer with project value between Rp.2.5-100 billion. About supply strategy respondents state that there are variations in paying method used among suppliers with value of $55 \%$ and average score of 4.30 , whereas the shipping is considered good with the value of $53 \%$ and average score of 4.46 . Whilst for the availability of the needed capacity, respondents state that it is fulfilled with value of $50 \%$ and average score of 4.54 . On the other hand, respondents also state that coordination with supplier is convenient enough with value of $51 \%$ and average score of 4.54 .

Over price satisfaction respondents states that changing of price is rarely happen with value of $52 \%$ and average score of 4.30 . Respondents also state that pricing information from supplier is up-to-date with value of $52 \%$ and average score of 4.43 . Meanwhile in quality control of cement, respondents state that it is good enough with value of $38 \%$ and average score of 4.46. Other than that, respondents also state that certification of cement is already complete with value of $57 \%$ and average score of 4.59 . Respondents also state that they are 
experienced with value of $46 \%$ and average score of 4.44 . Meanwhile in building relationship, respondent state that it is sufficient with value of $50 \%$ and average score of 4.32. More, respondent state that the reputation of suppliers is good with value of $50 \%$ and average score of 4.31. Lastly, respondent also state that supplier are quite reliable with value of $38 \%$ and average score of 4.51 .

Over commitment variable, for willing to stay with the same supplier indicator, respondents value it with $54 \%$ with average score of 4.55 . At the same time, respondents also state that they will recommend the supplier they use with value of $51 \%$ and average score of 4.49. In satisfaction variable, over satisfaction indicator respondents state that they are content with the supplier they use with value of $55 \%$ and average score of 4.52 . On the other hand, for the fulfillment of their wishes, respondent state that it is enough with value of $53 \%$ and average score of 4.44 . And for long-term relationship, for the indicator of will keep using same supplier, respondent state that they will stay with same supplier with value of $52 \%$ and average score of 4.56 . Moreover, respondents state that they will further develop better cooperation with suppliers with value of $67 \%$ and average score of 4.49 .

The Influence of Relationship Quality towards Long-term Relationship in Buying Cement According to Developer as the Buyer towards the Supplier. From analyzing the data using $A M O S$ as the tools, the final model shows as figure below.

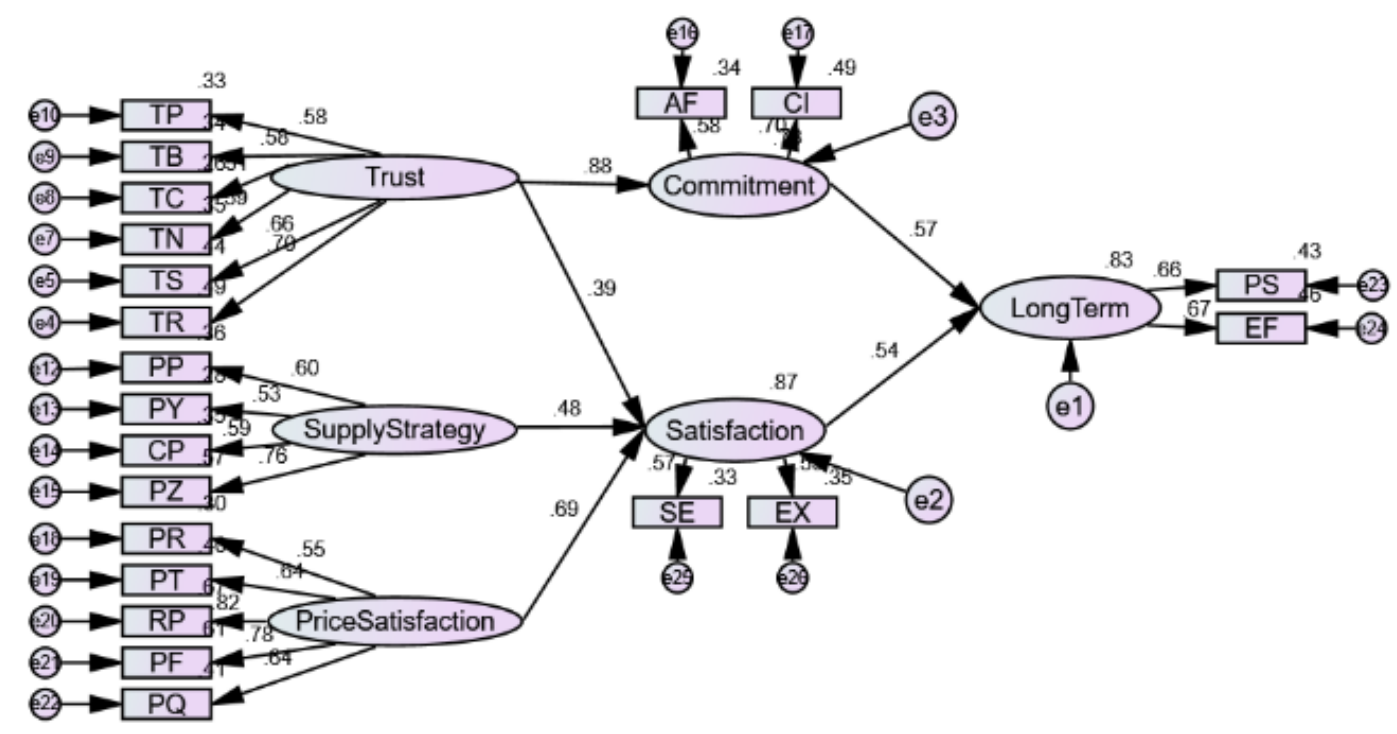

Figure 3 - Scheme of results analysis

Testing the relationship between latent variables and the manifest (indicators) is conducted. Discovered that the relationship direction is represented by estimate value and significance is represented by $\mathrm{CR}$ with criterion $>1.96$ and/or $\mathrm{P}$ with criterion of $<0.05$. According to hair et al., (2010), when the estimate value of the indicator is below 0.5, therefore it is discarded from the model.

There is removal of indicators in trust section which are TI and TE due the lack of value $(<0.5)$. At the same time, the other variables have same or constant indicator.

Correlation between supply strategy and satisfaction proven to have positive direction $(0.48)$ and significance of $(2.69>1.96)$. Moreover, $p$ value which is 0.007 which is far below the cut off value of 0.05 means that $H_{0}$ is lacking, or it means that there is obvious correlation between supply strategy variable and satisfaction variable. Whereas at estimate value, obtained $0.484<0.5$ which means that supply strategy gives less influence towards satisfaction. Seen from the significance and positive direction, this outcome is caused by the supplier that is able to give attractive payment method to the consumer which is either building developer or project contractor. Moreover, supplier is able to fulfill the shipping requirement (on time), easy to coordinate with and also has the capacity to fulfill the needed 
quota of the consumer. This is in line with Bulele's (2016) research which explains that the availability of the product gives huge impact on the decision and satisfaction, related to product buying.

Table 3 - Indicator correlation

\begin{tabular}{|c|c|c|c|c|}
\hline \multicolumn{5}{|c|}{ Supply Strategy } \\
\hline Code & Indicator & Estimate & C.R. & $\mathrm{P}$ \\
\hline $\mathrm{PZ}$ & Capacity availability & 0.76 & & \\
\hline $\mathrm{CP}$ & Simplicity coordination & 0.59 & 5.22 & .000 \\
\hline PY & On time shipping & 0.53 & 4.73 & .000 \\
\hline PP & Payment method variations & 0.60 & 5.18 & .000 \\
\hline \multicolumn{5}{|c|}{ Price satisfaction } \\
\hline Code & Indicator & Estimate & C.R. & $\mathrm{P}$ \\
\hline$P Q$ & Cement's pricing corresponding with quality & 0.64 & & \\
\hline PF & Appropriate cement's price & 0.78 & 7.03 & .000 \\
\hline $\mathrm{RP}$ & Cement's price is cheap & 0.82 & 6.98 & .000 \\
\hline $\mathrm{PT}$ & Price information from supplier & 0.63 & 5.89 & .000 \\
\hline PR & Cement's change in price & 0.54 & 5.18 & .000 \\
\hline \multicolumn{5}{|c|}{ Trust } \\
\hline Code & Indicator & Estimate & C.R. & $\mathrm{P}$ \\
\hline TR & Product Reputation & 0.69 & & \\
\hline TS & Product Information & 0.67 & 6.60 & .000 \\
\hline $\mathrm{TI}$ & Good quality control & 0.37 & 3.72 & .000 \\
\hline TN & Cement's certification & 0.60 & 5.70 & .000 \\
\hline $\mathrm{TC}$ & Experienced Supplier & 0.50 & 4.91 & .000 \\
\hline TB & Supplier conducting good relationship & 0.59 & 5.66 & .000 \\
\hline TP & Supplier has good reputation & 0.58 & 5.56 & .000 \\
\hline TE & Supplier is dependable & 0.47 & 4.59 & .000 \\
\hline \multicolumn{5}{|c|}{ Commitment } \\
\hline Code & Indicator & Estimate & C.R. & $\mathrm{P}$ \\
\hline AF & Keep wanting to use & 0.59 & & \\
\hline $\mathrm{Cl}$ & Recommending & 0.70 & 4.99 & .000 \\
\hline \multicolumn{5}{|c|}{ Satisfaction } \\
\hline Code & Indicator & Estimate & C.R. & $P$ \\
\hline EX & Expectation fulfilled & 0.59 & & \\
\hline SE & Satisfied with supplier & 0.57 & 6.94 & .000 \\
\hline \multicolumn{5}{|c|}{ Long-term Relationship } \\
\hline Code & Indicator & Estimate & C.R. & $\mathrm{P}$ \\
\hline PS & Always buying cement at the supplier & 0.66 & & \\
\hline EF & Establishing better cooperation & 0.67 & 7.78 & .000 \\
\hline
\end{tabular}

Price Satisfaction towards satisfaction proven to be resulting in positive value $(0.69)$ and significance of $(3.93>1.96)$. Furthermore, the low $p$ value which is 0.000 and far below its cut off value of 0.05 which means that $H_{0}$ is lacking, or in other words there is actual correlation between price satisfaction variable and satisfaction variable. Whereas at estimate value, the result is $0.692>0.5$ which means that price satisfaction is closely related to satisfaction. Basically, the behavior of supplier that is rarely changing its price, or when there is increase in the price it is still categorized in reasonable zone and also gives information at the same time, gives big impact towards the consumer which is businessman or project holder. This is in line with a research conducted by Fuyaye (2011) which explains that price gives huge impact on satisfaction where the price that is stable and does not easily go up abruptly will make the consumer feel safe and comfortable.

Trust towards satisfaction results in positive influence of (0.39) and significance of (2.28>1.96). Furthermore, the number of $p$ that is 0.023 which is still far below its cut off value of 0.05 means that $H_{0}$ is lacking, or that there is actual correlation between trust variable and satisfaction variable. Whereas, the value of estimate that is $0.392<0.5$ means that trust does not closely influence satisfaction. This is the result of the guaranteed quality, the complete certification and clear product information of the brand that the supplier sells. This is in line with a study conducted by Razak et al. (2016) which states that trust gives 
influence in increasing satisfaction, yet for product with already good reputation this is not really important as there is already trust from consumer towards the brand.

Table 4 - Hypothesis Testing

\begin{tabular}{|c|c|c|c|c|c|c|}
\hline & Hypothesis & & & Estimate & $\mathrm{P}$ & Information \\
\hline $\mathrm{H} 1$ & Supply Strategy & $--->$ & Satisfaction & 0.48 & .007 & Positive and Significant \\
\hline $\mathrm{H} 2$ & Price Satisfaction & $--->$ & Satisfaction & 0.69 & .000 & Positive and Significant \\
\hline $\mathrm{H} 3$ & Trust & $-->$ & Satisfaction & 0.39 & .023 & Positive and Significant \\
\hline $\mathrm{H} 4$ & Trust & $--->$ & Commitment & 0.88 & .000 & Positive and Significant \\
\hline H5 & Satisfaction & $--->$ & Long-term & 0.54 & .001 & Positive and Significant \\
\hline $\mathrm{H} 6$ & Commitment & $-->$ & Long-term & 0.57 & .016 & Positive and Significant \\
\hline
\end{tabular}

Correlation between trust and commitment has positive value of $(0.88)$ and significance of (4.95). Furthermore, the small value of $p$ which is 0.000 and below its cut off value of 0.05 means that $H_{0}$ is lacking, or there is actual correlation between trust variable and commitment variable. Whereas, at estimate value the result is $0.884>0.5$ which means trust closely gives influence towards commitment. This is caused by trust that brings out commitment gesture. Whilst known that reputation of a product and supplier gives big influence towards increasing commitment between both stakeholders. This is confirmed with a study by Kwon and Suh (2004) stating that commitment can be established by trust, yet in the process of increasing trust, consistency and reliability in giving service or holding business is needed.

Satisfaction gives positive value of $(0.54)$ and significance of $(3.23>1.96)$ towards longterm relationship. Whereas, the value of $p$ that is 0.001 which is far below its cut off value 0.05 means that $H_{0}$ is lacking, in another words there is actual correlation between satisfaction variable and long term relationship. Furthermore, the estimate value shows $0.541>0.5$, meaning that satisfaction closely influences long-term relationship. It is because satisfaction can encourage the consumer to use same product while also recommending it to others. On the other hand, it is the result of product and supplier's performance that fulfill the expectation. It is in line with a study by Fierro and Redondo (2010) stating that satisfaction of consumer gives influence towards long-term purchasing activity; this is because the consumer will not need to look for another supplier to get a same product.

Commitment has positive value $(0.57)$ and significance of $(2.41>1.96)$ towards longterm relationship. Furthermore, value of $p$ which is 0.016 , is still below its cut off value of 0.05 , meaning that $H_{0}$ is lacking, on another words there is actual relation between commitment variable and long-term relationship variable. The reason is because commitment can develop long-term purchasing activity, shown by the strong trust of consumer and the unwillingness to use another supplier. It is in line with the study by Zhao at al. (2008) stating that high degree of commitment from consumer towards a certain product of certain company will lead to willingness of staying with the mentioned product.

In the buying decision making, there are several things that are noted by the developer. One of them is the need to maintain commitment and satisfaction in order to preserve and enhance the long-term buying relationship, as explained by Kamil and Gurkan (2013) stating that satisfaction and commitment are able to give direct influence towards long-term relationship. On the other hand this gives indirect result towards recommendation from consumer to another consumer. There are several aspects to be noted by supplier that focuses into developer (respondent) as its market target, they are:

In order to increase trust, the suggested strategy related to product's information is by using separated communication tools both via SMS and Whatsapp which is especially used for certain developer as a consumer by always giving updated information related to cement product, such as product specification, stock available, price changes, as far as shipping time needed. Furthermore, the product reputation needs to be improved through giving bonuses, as well as competitive price. This is in line with Saura et al. (2009) stating that trust leads to commitment. Improving trust can be done by improving product's reputation, which becomes common reason for a consumer choosing a product. Furthermore there is a need to inform consumer about product's specifications and certification. Not only from the aspect of the 
product, but the supplier's reputation in establishing relationship and communication also very important.

In order to improve the price satisfaction, the strategies suggested are by suppressing the price change through reducing the profit taken, particularly in the busy months, therefore this attract developers to buy in large quantity that improves the profit that supplier's get through quantity selling. Furthermore, discounts for large quantity buying need to be given in order to attract more developers as consumers. This is parallel with a study by Lungtae and Atthirawong (2014) which states that there is direct influence of price satisfaction towards satisfaction. In order to achieve that, supplier needs to pinpoint 3 important aspects, they are: relative price, price fairness, and price-quality ratio. The lowest price is the be top priority for respondent for the reason that it improves the profit of that respondent. The fairness of the price balanced with the acceptable quality is also an aspect to be noted. This strategy is accordance with Lungtae and Atthirawong (2014) which state that there is need to focus on establishing perception through fair, reliable and suitable price to the quality, also systematic pricing standards. Furthermore, the price change needs to be minimalized, while if that happens, consumer needs to be informed beforehand because it is very influential towards the changes in the budget plan.

Improving supply strategy, the strategy suggested is through paying method variation, by providing various types of term payment method where the more consumer buy from the supplier, the longer the paying term. Furthermore, data of the available product need to be collected as well as doing repeat order if needed to keep the availability of the product. This is in line with a statement by Gyau et al. (2011) saying that capacity of purchase may affect the quality of relationship between organizations, while Lungtae and Atthirawong (2014) state that coordination in cooperation and payment methods give influence towards consistency of the demand.

\section{CONCLUSION}

Based on the data distribution in the price satisfaction, supply strategy, trust, commitment, and satisfaction variables, most of the responses of the respondents are categorized as agree descriptively. From the indicator of supply strategy, availability of capacity and simplicity of coordination are able to give 'good' value category for the respondents. Whereas, at trust indicator; quality control, cement certification, and experienced supplier also able to give 'good' category towards respondents. In the commitment variable, the willingness to keep using the product and willingness to recommend the product also give 'good' value and in satisfaction variable, for the satisfaction towards supplier and fulfilled expectation also in the 'good' category range. For long-term relationship, for willingness to buy and willingness to establish better cooperation also in the 'good' category range. This is emphasizing that with high satisfaction degree from the developer, the long-term relationship is improved and with high degree of commitment, the long term relationship is preserved. Furthermore, the variable of supply strategy, price satisfaction and trust have actual influence towards satisfaction while trust variable also has actual influence towards commitment. Likewise, the variable satisfaction and commitment also give actual influence towards long-term relationship.

There is a need to improve commitment through increasing trust. Furthermore, satisfaction also needs to be improved through supply strategy; therefore it improves the long-term relationship. In improving trust, there are several aspects to be noted, which are: product's reputation, product's information, supplier's relation, and supplier's reputation. While at price satisfaction there are several aspects that able to give influence, including low price of the cement, fairness of the price, price that correspond with quality, also clear information about the price change and the scarcity of it happening. Furthermore, in supply strategy variable, there are several indicators that need to be noted, including the availability of product's capacity, payment methods variation, simplicity of coordination, and the punctual shipping time. 


\section{REFERENCES}

1. Aistè Dovalienè, Agnè Gadeikienè, Žaneta Piligrimienè. 2007. Customer Satisfaction and its Importance for Long-Term Relationships with Service Provider: the Case of Odontology Service. Commerce of Engineering Decisions. 5 (53).

2. Alison M. Dean. 2007. The Impact of the Customer Orientation of Call Center Employees on Customers' Affective Commitment and Loyalty. Journal of Service Research. 10: 161.

3. Arbuckle, J. L., 2003. Amos 5.0 Update to The Amos User's Guide, Small Water Corporation, Chicago.

4. Armando Luís Vieira, Heidi Winklhofer and Christine T. Ennew. 2008. Relationship Quality: A Literature Review and Research Agend. Journal of Customer Behaviour. 7 (4): 269-291.

5. Ballester, E. D. and Jose Luis, M. A. 2001. Brand Trust in the Context Of Consumer Loyalty. European Journal of Marketing. 35.

6. Boniface B, Gyau A, and Stringer R. 2009. Relationship Quality as The Predictor Of Long Term Relationship In The Malaysian Dairy Industry. Journal of Marketing and Logistics, 66-76.

7. Boniface B. 2012. Producer Relationship Segmentation In Malaysia's Milk Supply Chain. British Food Journal, 114 (10).

8. Boniface B, Gyau A, and Stringer R. 2012. Linking Price Satisfaction And Business Performance In Malaysia's Dairy Industry. Asia Pacific Journal of Marketing and Logistics, 24 (2): 288-304.

9. Bricci L, Fragata A, and Antunes JG. 2015. The Effects of Trust, Commitment, and Satisfaction on Consumer Loyalty in the Distribution Sector. Journal of Business Economy and Management.

10. Bulele, Ester Y. 2016. Analisis Pengaruh Citra Toko, Kualitas Pelayanan and Ketersediaan Produk Terhadap Keputusan Pembelian di Toko Buku Gramedia Manado. Jurnal Berkala IImiah Efisiensi. 16(3): 258-268.

11. Byrne, B.M., 2001. Structural Equation Modelling With AMOS: Basic Concepts, Applications, and Programming. Lawrence Erlbaum, New Jersey.

12. Canavari M, Fritz M, Hofstede GJ, Matopoulos A, and Vlachopoulou M. 2009. The Role Of Trust In The Transition From Traditional To Electric B2B Relationships In Agri-Food Chains. Computer and Electronic in Agriculture 70: 321-327.

13. Dietrich Von Rosen, 1989. Maximum Likelihood Estimators in Multivariate Linier Normal Models. Journal of multivariate analysis. 31.

14. Essig A, and Amann M. 2008. Supplier Satisfaction: Conceptual Basics and Explorative Findings. Journal of Purchasing \& Supply Management 15: 103-113.

15. Fierro, Jesus J Cambra. Redondo, Yolanda Polo. 2010. Post-Satisfaction Factors Affecting The Long-Term Orientation Of Supply Relationships. Journal of Business \& Industrial Marketing. 26(6): 395-406.

16. Fuyane, Nikululeko. 2011. How Does Price And Quality of A Service Affect Customer Satisfaction With Reference to Cross-Border (Zimbabwe-South Africa) Public Transport. [Tesis]. National University of Science and Technology. Afrika.

17. Garbarino, E. and Johnson, M.S. 1999. The Different Roles of Satisfaction, Trust and Commitment in Customer Relationships. Journal of Marketing. 63 (2): 70-87.

18. Gao Shengyi, Mokhtarian Patricia L., Johnston Robert A., 2008. Non Normality of Data in Structural Equation Models. California Digital Library. UC. Berkeley. University of California.

19. Geoffrey M. Maruyama. 1998. Basics of Structural Equation Modeling.

20. Gerrit H. Van Bruggen, Manish Kacker, Chantal Nieuwlaat. 2001. The Impact Of Channel Function Performance On Buyerseller Relationships In Marketing Channels. Erasmus Research Institute of Management. 35.

21. Ghozali I. and Fuad. 2008. Structural Equation Modeling. 
22. Gustaffsson A, Johnson MD, and Roos I. 2006. The Effects of Customer Satisfaction, Relationship Commitment Dimensions, and Triggers on Customer Retention. Journal of Marketing. 69: 210-218.

23. Gyau A, 2011. Price Or Relational Behaviours? Supplier Relationship Management In The German Dairy Industry. British Food Journal, 113 (7): 838-852.

24. Hair, J.F., W.C. Black, B.J. Babin, R.E. Anderson and R.L. Tatham, 2006. Multivariate Data Analysis. $6^{\text {th }}$ Edition, Prentice Hall, Upper Saddle River, NJ., USA., 928.

25. Hasan, M. Iqbal. 2001. Pokok-pokok Materi Metodologi Penelitian and Aplikasinya.

26. James Kelly S. 2004. Measuring Attitudinal Commitment In Business-To-Business Channels. Marketing Intelligence \& Planning, 22 (6): 636-651.

27. Jose-Ramon Segarra-Moliner, Miguel-Angel Moliner-Tena and Javier Sa 'nchez-Garcia. 2013. Relationship Quality In Business To Business: A Cross-Cultural Perspective From Universities. Business Administration and Marketing Department. 31 (3).

28. Kumar Das B, and Sharma S. 2017. Influence of Relationship \& Behavioural Aspects on Customer Retention \& Loyalty in B2B Flexible Packaging Industry in Bangladesh. International Journal of Applied Business and Economic Research, 15 (22).

29. Kwon, 2004. Factors Affecting the Level of Trust and Commitment in Supply Chain Relationships. Journal of Supply Chain Management. 2(1): 1-12.

30. Lariviere B, 2013. A Longitudinal Examination of Customer Commitment And Loyalty. Journal of Service Management, 25 (1): 75-100.

31. Liu L.-W., Yang W.-G., Liu W.-H. 2017. Building the B2B Customer Loyalty: A Role Of Relationship Quality. Polish Journal Of Management Studies. 16 (1).

32. Lungtae S, 2014. Development And Retaining Model Of Long-Term Relationship Between Buyers And Sellers In Supply Chain Of Palm Oil Industry In Thailand: A Seller's Perspective. Research Journal of Business Management, 8 (4): 300-318.

33. Meena, P.L. and S.P. Sarmah, 2012. Development of a Supplier Satisfaction Index Model. Ind. Manage. Data Syst., 112: 1236-1254.

34. Natalia F. 2014. Pengaruh Brand Image, Kualitas Produk, and Harga Terhadap Keputusan Pembelian Pada Pt Chandra Jaya Sukses (Produk Kursi Recliner Merek Lazboy). Jurnal Akuntansi and Manajemen Esa Unggul, 2 (2): 1-384.

35. Perry R. Hilton Charlotte, Brownlow Isabella, McMurray \& Bob Cozens, (2004). SPSS Explained. Routledge Taylor and Francis Group. London \& New York. 363-364.

36. Razak, Ismail. Nirwanto, Nazief. Triatmanto, Boge. 2016. The Impact of Product Quality and Price on Customer Satisfaction with the Mediator of Customer Value. Journal of Marketing and Consumer Research. 30 (1): $59-69$.

37. Rungson Chomeya. (2010). Quality of Psychology Test Between Likert Scale 5 and 6 Points. Journal of Social Sciences, 6 (3): 399-403.

38. Saura, I.G., M.F. Deltoro and M. Hartmann, 2009. The Value of B2B Relationship. Ind. Manage. Data Syst., 109: 593-609

39. Shaoling Fu, Jiawei Huang, Yanmei Yan and Yangjun Ou. (2014). Research on Undergraduates Continuous Using Behaviors of WeChat: Data from China. Journal of Chemical and Pharmaceutical Reseaarch, 6 (6): 125-130.

40. Santoso S. 2018. Konsep Dasar Aplikasi SEM dengan Amos 24.

41. Sumarwan U. 2014. Perilaku Konsumen, Second Edition.

42. Sumarwan U. 2017. Metode Riset Bisnis and Konsumen.

43. Somogyi S, Gyau A, Li E and Bruwer J. 2010. Enhancing Long-Term Grape Grower/Winery Relationships In The Australian Wine Industry. International Journal of Wine Business Research, 22 (1): 27-41.

44. Zhao, Xiande. Huo, Baofeng. Flynn, Barbara, Yeung, Jeff Hoi Yan. 2008. The Impact Of Power And Relationship Commitment On The Integration Between Manufacturers And Customers In A Supply Chain. Journal of Operations Management. 26(1): 368-388.

45. Zhang Z, Waszink Ab, and Wijngaard J. 1999. An Instrument for Measuring TQM Implementation for Chinese Manufacturing Companies. International Journal of Quality \& Reliability Management, 17 (7): 730-755. 